\title{
Biomagnification of mercury in a marine grazing food-chain: algal cells Phaeodactylum tricornutum, mussels Mytilus edulis and flounders Platichthys flesus studied by means of a stepwise- reduction-CVAA method
}

\author{
Hans Ulrik Riisgård, Susanne Hansen
}

Institute of Biology, Odense University, Campusvej 55, DK-5230 Odense M, Denmark

\begin{abstract}
A stepwise-reduction-cold vapor atomic absorption spectrometry (CVAA) method has been further developed. The method is relatively simple and quick and allows measurements of both inorganic and organic mercury in the same small biological sample. It provides an effective technique for studying biomagnification of mercury in a marine grazing food-chain (algae/mussels/fish). In laboratory experiments with mussels exposed to both inorganic mercury (965 $\mathrm{ng} \mathrm{l}^{-1}$ ) and organic mercury (methylmercury) ( $35 \mathrm{ng} \mathrm{l}^{-1}$ ), and fed algal cells at a natural low concentration from a chemostat for $80 \mathrm{~d}$, uptake of both mercury species was linear. Organic mercury was taken up 15 times more readily than inorganic mercury. Flounders force-fed with food contaminated with equal concentrations of organic and inorganic mercury for $46 \mathrm{~d}$ readily accumulated organic mercury in blood cells, liver, kidney and muscle-tissue while inorganic mercury was only accumulated in measurable amounts in liver and kidney. During an elimination experiment $(48 \mathrm{~d})$ with both force-fed and starved flounders (loaded with mercury), organic mercury concentration did not decrease in the muscle-tissue, but significantly decreased in the liver, kidney and blood cells, while inorganic mercury tended to increase in the liver. Thus organic mercury may be biotransformed to inorganic mercury in the liver. Relatively low concentrations of organic mercury in the gall bladder indicate that enterohepatic recirculation may not play a similar role in fish as reported for mammals. Higher mercury concentrations in the proximal part of the intestine compared to the dista! part show, however, that some mercury may be secreted via the bile and reabsorbed, but no differences between fed and starved fish were found. Though only about $1 \%$ of the total mercury in chronically polluted waters may be in the organic form, an enhanced uptake rate of organic mercury in mussels leads to differential partitioning of the 2 mercury forms. Since fish such as flounder may primarily feed on juvenile bivalves about $75 \%$ of the total mercury ingested by fish may be in the inorganic form. The efficient accumulation of organic mercury and the lack of elimination results in an increasing organic mercury concentration with both age and trophic level (i.e. biomagnification) in the marine grazing food-chain.
\end{abstract}

\section{INTRODUCTION}

Discharges of mercury to the marine environment are primarily in the form of inorganic mercury $\left(\mathrm{Hg}^{0}, \mathrm{Hg}^{++}\right)$ As a result of microbial transformations of inorganic mercury to organic monomethylmercury $\left(\mathrm{CH}_{3} \mathrm{Hg}^{+}\right)$, a certain part of the total mercury in both sediments and suspended matter in the water column, including phytoplankton, is in organic form (Vonk \& Sijpesteijn 1973, Beijer \& Jernelöv 1979, Topping \& Davis 1981, Compeau \& Bartha 1984). Though only a low percentage of the total mercury in sediment, suspended matter and planktonic algae, may be organic, the largest fraction of the total mercury in marine fish is monomethylmercury (Knauer \& Martin 1972, Gardner et al. 1978, Huckabee et al. 1979, Windom \& Kendall 1979, Clarkson et al. 1984, Mikac et al. 1985, Riisgård \& Famme 1986). Numerous studies on mercury in marine fish have led to this basic knowledge, but relatively little information has been obtained to understand the mechanisms by which methylmercury is accumulated in food-chains. In invertebrates, which occupy intermediate positions in 
the food-chain, the percentage of methylmercury in relation to total mercury content varies considerably from a few to near $100 \%$ (Møhlenberg \& Riisgård 1988). Insufficient information is available concerning the fundamental principles of biomagnification processes in marine food-chains which may lead to dangerously high concentrations of toxic methylmercury in top predators (i.e. fish eaten by man) in mercury-polluted areas (cf. Rabenstein 1978). Knowledge of the accumulation, distribution, metabolism and elimination of both inorganic and organic mercury in phytoplankton, suspension feeders (zooplankton, suspension feeding macroinvertebrates, e.g. bivalves) and fish is essential for obtaining a more detailed description of the biomagnification ('transfer up the food chain') of organic mercury in the marine grazing food-chain. One of the main reasons for the lack of such knowledge seems to be due to analytical difficulties in distinguishing the different chemical forms of mercury in the same sufficiently small biological sample (Riisgård et al. 1985).

The aim of the present work has been to further develop and describe a relatively simple and quick method which allows measurement of both inorganic and organic mercury in the same small biological sample. Further, we present results using this method and demonstrate that it provides an effective technique for studying the biomagnification of mercury in marine grazing food-chains.

\section{MATERIALS AND METHODS}

Algal and mussel experiments. Accumulation of mercury in algal cells: Experiments were performed on algal cells from the same pure chemostat culture of Phaeodactylum tricornutum as used in the 'laboratory mussel experiments' (see below). The growth medium consisted of autoclaved natural seawater (ca $20 \%$ S) enriched with nutrients, but without EDTA or other chelators. The algal concentration in the chemostat culture was $8 \times 10^{6}$ cells $\mathrm{ml}^{-1}$. Algal cells to be used in accumulation experiments were centrifuged and the pellets resuspended in clean seawater. The accumulation of $100 \mathrm{ppb}$ inorganic mercury was studied by adding mercury $\left(\mathrm{HgCl}_{2}\right)$ to $500 \mathrm{ml}$ suspensions of $2 \times 10^{5}$ and $6 \times 10^{4}$ algal cells $\mathrm{ml}^{-1}$. After different exposure times (0 to $332 \mathrm{~min}$ ) the culture samples $(80 \mathrm{ml})$ were centrifuged and the pellets analysed for mercury

Laboratory mussel experiment: Mussels Mytilus edulis were collected in May 1985 in the Great Belt near the Biological Station at Bogebjerg, Funen, Denmark. At the Biological Station 200 mussels (ca 25 to $35 \mathrm{~mm}$ shell length) were selected and placed in an aquarium (30 l) with flowing seawater $\left(10 \mathrm{ml} \mathrm{min}^{-1}\right.$ $14.5^{\circ} \mathrm{C} ; 21 \pm 3 \%$ S). Phaeodactylum tricornutum were continuously added from a $200 \mathrm{l}$ chemostat culture to ensure an algal concentration of 7 to $8 \times 10^{3}$ cells $\mathrm{ml}^{-1}$ Organic mercury $\left(\mathrm{CH}_{3} \mathrm{HgCl}\right)$ and inorganic mercury $\left(\mathrm{HgCl}_{2}\right)$ were added to the aquarium from 2 stock solutions by means of a peristaltic pump to give a nominal total mercury concentration of $1 \mu \mathrm{g} \mathrm{l}^{-1} \quad(=1$ $\mathrm{ppb}$ ) of which $35 \mathrm{ng} \mathrm{l}^{-1}$ was in the organic form. The algal concentration was measured nearly every day (by means of an Elzone $80 \mathrm{XY}$ electronic particle counter) and the algal dosing pump was adjusted during the exposure period to compensate for removal of mussel samples ( 8 individuals which were split into 2 size groups: 'small' (I) and 'large' (II) individuals) on Days 0, $6,13,20,26,33,40,44,56,61,70$ and 80 . The mussels were observed to be wide open and actively filtering during the whole experimental period. Because $P$. tricornutum is retained with $100 \%$ efficiency by $M$. edulis (Møhlenberg \& Riisgård 1978), the algal ingestion rate (to be used for estimating the mercury intake via food) was found by multiplying the mean algal concentration measured in the aquarium by the estimated filtration rate for the 2 size groups (I and II) using the equation for the relationship between size (W, $g$ dry wt) and filtration rate $\left(F, \mathrm{I} \mathrm{h}^{-1}\right)$ given by Møhlenberg \& Riisgård (1979): $F=7.45 W^{0.66}$. Wet wt of soft parts was converted to dry wt by dividing by 5 (own obs.).

Field mussel experiment: In September 1986 clean Mytilus edulis were collected in the Sallingsund in the central part of the Limfjord, Denmark. A size class of 40 to $60 \mathrm{~mm}$ was selected and placed in net bags suspended at 3 localities (near sampling sites 7, 8 and 9 on Fig. 1 in Møhlenberg \& Riisgård 1988) at a depth of 3 to $5 \mathrm{~m}$ and about $300 \mathrm{~m}$ offshore, in the chronically mercury polluted southwestern Nissum Broad (cf. Kiørboe et al. 1983, Riisgård 1984, Riisgård \& Famme 1986). On Day 0 and at intervals during the following $57 \mathrm{~d}$, mussel samples (about 20 individuals) were collected 4 times, and 5 mussels (about $50 \mathrm{~mm}$ shell length) were taken for mercury analysis. The mussels were transplanted together with flounders to specially designed net-cages located on the sea-bottom in which the net-bags with mussels were placed. (As no mercury accumulation could be measured in the transplanted flounders these experiments are not reported in this paper). Mean water temperature was about $12{ }^{\circ} \mathrm{C}$ and the salinity about $32 \%$.

Fish experiments. Flounders Platichthys flesus were caught in the Odense Fjord, Denmark, in May 1987 ('accumulation experiment') and September 1987 ('elimination experiment') and brought to the nearby Biological Station, Odense University. The fish (mean body weight about $230 \mathrm{~g}$ ) were transferred to tanks (500 or $1500 \mathrm{l}$ ) with 2 to $3 \mathrm{~cm}$ fine-grained sand on the 
bottom and flowing seawater $(21 \pm 3 \%$ S) from the open laboratory water system (total volume of water changed 5 to 18 times per day). During the accumulation experiment' the temperature rose from 8.6 to $11.8^{\circ} \mathrm{C}$ while it decreased from 13.8 to $6.2^{\circ} \mathrm{C}$ during the 'elimination experiment'.

Accumulation experiment: Flounders were force-fed with mercury-contaminated food prepared from minced cod-fillet $(100 \mathrm{~g})$ diluted with seawater $(150 \mathrm{ml})$ and homogenized (Ultra-turrax TP 18/2N). Dissolved $\mathrm{CH}_{3} \mathrm{HgCl}$ and $\mathrm{HgCl}_{2}$ were added to give a total mercury concentration of 2.5 to $3 \mathrm{ppm}$ with ca $50 \%$ of each mercury species (Table 1). The total mercury concentration was chosen because it falls within the range of

Table 1. (A) Mercury concentrations (ng $\mathrm{Hg} \mathrm{g}^{-1}$ wet wt $=\mathrm{ppb}$ ) \pm SD measured in samples of freshly prepared mercurycontaminated food used for force-feeding of flounders in 'accumulation experiment' (Accum. exp.) and for loading flounders with mercury prior to 'elimination experiment' (Elim. exp.); n: number of separate samples and analysis. (B) Consensus values for mercury concentrations (ng $\mathrm{Hg} \mathrm{g}^{-1}$ dry wt) \pm SD from lCES First Round Intercalibration for methylmercury in biological tissue shown together with data from Odense University (OU; method used in present work) and the Danish Isotope Centre (DIC; Neutron Activation Analysis) (Sample $\mathrm{E}=$ dog-fish muscle; Sample $\mathrm{H}=$ blue mussel). (C) Data from internal intercalibration between OU and DIC using a sample of freeze-dried homogenized tuna muscle. $\mathrm{n}$ : number of replicate analyses in (B) and (C)

\begin{tabular}{|c|c|c|c|c|}
\hline & $\mathrm{n}$ & $\begin{array}{l}\text { Inorg. } \mathrm{Hg} \\
(\mathrm{ppb})\end{array}$ & $\begin{array}{l}\text { Org. Hg } \\
\text { (ppb) }\end{array}$ & $\begin{array}{l}\text { Total Hg } \\
\text { (ppb) }\end{array}$ \\
\hline A. Accum exp. & 14 & $1523 \pm 415$ & $1150 \pm 476$ & $2673 \pm 852$ \\
\hline Elim. exp. & 11 & $1725 \pm 370$ & $1330 \pm 207$ & $3058 \pm 564$ \\
\hline \multicolumn{5}{|l|}{ B Sample E } \\
\hline DIC & 6 & & $985 \pm 72$ & $2114 \pm 180$ \\
\hline OU & 6 & & $862 \pm 90$ & $1853 \pm 93$ \\
\hline \multicolumn{5}{|l|}{ Sample H } \\
\hline ICES & & & $56 \pm 14$ & $180 \pm 30$ \\
\hline $\mathrm{DIC}$ & 6 & & $56 \pm 4$ & $180 \pm 9$ \\
\hline OU & 6 & & & $109 \pm 35$ \\
\hline \multicolumn{5}{|l|}{ C Tuna } \\
\hline DIC & 30 & & $480 \pm 36$ & \\
\hline $\mathrm{OU}$ & 8 & & $487 \pm 73$ & \\
\hline
\end{tabular}

measured mercury concentrations in fish-prey organisms in polluted marine areas (e.g. Kiørboe et al. 1983). The experimental fish were fed $2 \mathrm{ml}$ food ( 5 to $6 \mu \mathrm{g}$ total $\mathrm{Hg}) 3$ times per week by means of a syringe extended with a $10 \mathrm{~cm}$ plastic tube which was gently inserted through the mouth into the stomach. Prior to accumulation experimental fish were acclimated for $3 \mathrm{~d}$ in the laboratory. On Days $0,7,14,21,28,37$ and 46,4 or 5 fish were removed for mercury analysis. From each fish a blood sample $(2 \mathrm{ml}$ ) was taken from the tail vein by means of an injection syringe. Two drops of heparin were added to prevent coagulation, and the samples were centrifuged $(120 \times g$ for $5 \mathrm{~min})$ to separate blood cells and plasma. The fish were killed and samples of filet-muscle, liver, kidney and gall bladder were taken. All samples were frozen until mercury analyses could be made. No significant difference ( $p>0.1$, t-test) between body weight on Day 0 and Day 46 was noticed.

Elimination experiment: For $6 \mathrm{wk}$ flounders were force-fed with mercury contaminated food as in the 'accumulation experiment' (Table 1), but the same weekly dose was given as $3 \mathrm{ml}$ food ( 7.5 to $9 \mu \mathrm{g}$ total $\mathrm{Hg}) 2$ times per week. Then the fish were separated (Day 0) into 2 groups, one which was fed the same uncontaminated food ration as previously (Group A), and one which was starved (Group B).

Mercury in feces: On Days 10, 31 and 48 during the 'elimination experiment' samples of feces were taken from a number of fish from the group which was forcefed with uncontaminated food. Two feces samples were also taken on the last day (Day 46) of the accumulation experiment'. Feces samples were taken using a plastic scalpel from the proximal and/or distal part of the intestine by removing about $5 \mathrm{~cm}$ of excised intestine which was then cut open to remove the feces. The feces samples were then frozen until analyses for mercury could be made.

Mercury analyses. Concentrations of inorganic and organic mercury in biological samples were determined by selective reduction and cold vapor atomic absorption spectrometry (CVAA). The method involves first a chemical reduction of inorganic mercury $\left(\mathrm{Hg}^{++}\right)$ to elemental mercury $\left(\mathrm{Hg}^{0}\right)$. Then the organic mercury is broken down to inorganic mercury and chemically reduced to elemental mercury. The elemental mercury from the 2 (stepwise) reductions is separately swept out of solution with atmospheric air and directed to a long path observation cell where light absorption (wavelength $=253.7 \mathrm{~nm}$ ) is measured. The selective reduction of inorganic mercury is made by tin chloride $\left(\mathrm{SnCl}_{2}\right)$ and the remaining organic mercury is reduced by sodium borohydride $\left(\mathrm{NaBH}_{4}\right)$. This procedure makes possible a determination of the amount of each form of mercury in a single sample. The analysis takes ca 5 min. The method described below was modified from Oda \& Ingle (1981) and Riisgård \& Famme (1988)

Apparatus: A Perkin-Elmer Mercury Analyzer System (model MAS-50A) with a $155 \mathrm{~mm}$ long absorption cell was used for absorption measurements. The absorption peaks were displayed on a pen-recorder. A Vigereaux-tube was used as a reduction vessel. In the bottom was a plastic tube for air and liquid intake. The top of the reduction vessel was connected to the absorption cell via a $6 \mathrm{~cm}$ long (i.d. $3 \mathrm{~mm}$ ) glass drying tube 
loosely packed with glass spheres (350 to $500 \mu \mathrm{m}$ ). Heating the drying tube to ca $130^{\circ} \mathrm{C}$ by a Bunsen burner vaporized water from the reduction vessel, and decomposed certain gases produced in the reduction vessel into chemical species that do not absorb at $253.7 \mathrm{~nm}$.

Chemicals: The following chemicals were used in all analyses: $10 \mathrm{M} \mathrm{KOH}, 1 \%$ (w/v) $\mathrm{NaBH}_{4}$ in $0.05 \mathrm{M} \mathrm{KOH}$, $2 \%(\mathrm{w} / \mathrm{v}) \mathrm{NaCl}, 1 \%(\mathrm{w} / \mathrm{v}) \mathrm{SnCl}_{2}$ in $0.05 \mathrm{M} \mathrm{HCl}, 1 \%$ (w/v) $\mathrm{K}_{2} \mathrm{Cr}_{2} \mathrm{O}_{7}$ in $25 \% \mathrm{HNO}_{3}$, 1 -octanol, $\mathrm{HgCl}_{2}$ for inorganic $\mathrm{Hg}$ standard, $\mathrm{CH}_{3} \mathrm{HgCl}$ for organic $\mathrm{Hg}$ standard.

Decomposition of samples: Approximately $0.25 \mathrm{~g}$ (wet weight) (in the case of dry material ca $0.04 \mathrm{~g}$ ) sample material was transferred to $25 \mathrm{ml}$ glass vials. 2.5 $\mathrm{ml} \mathrm{KOH}(10 \mathrm{M})$ was added and the vials tightly capped with plastic lids and incubated for $60 \mathrm{~min}$ at $95^{\circ} \mathrm{C}$. When the samples had cooled to room temperature, 5 $\mathrm{ml} \mathrm{NaCl}(2 \%)$ was added, and the samples centrifuged at $600 \times g$ for $10 \mathrm{~min}$. The supernatant was decanted into a $100 \mathrm{ml}$ volumetric flask, and $34 \mathrm{ml}$ of $\mathrm{NaCl}(2 \%)$ and $1 \mathrm{ml} \mathrm{K} \mathrm{K}_{2} \mathrm{Cr}_{2} \mathrm{O}_{7}(1 \%)$ added.

Analysis procedure: (1) From the sample, $4.25 \mathrm{ml}$ was transferred to a test tube, and 2 drops of octanol and $0.75 \mathrm{ml}$ conc. $\mathrm{HNO}_{3}(65 \%)$ were added. (2) After $1.5 \mathrm{~min}, 1.00 \mathrm{ml} \mathrm{SnCl}_{2}(1 \%)$ was sucked into the reduction vessel. (3) A $5.00 \mathrm{ml}$ sample was sucked into the reduction vessel. The resultant elemental mercury was swept into the absorption cell where the absorbance at $253.7 \mathrm{~nm}$ was measured. The measured peak absorbance following $\mathrm{SnCl}_{2}$ reduction is due only to inorganic mercury. (5) $0.50 \mathrm{ml} \mathrm{K}_{2} \mathrm{Cr}_{2} \mathrm{O}_{7}$ (1\%) was then sucked into the reduction vessel. (6) $0.50 \mathrm{ml} \mathrm{NaBH}_{4}$ $(1 \%)$ was sucked into the reduction vessel. The measured peak absorbance following $\mathrm{NaBH}_{4}$ reduction is due to organic mercury. (7) When the baseline was back to the zero level again the reduction vessel was evacuated of its contents and rinsed with distilled water. Samples were always analysed twice.

Standards: A stock solution of $52 \mu \mathrm{g} \mathrm{ml} \mathrm{m}^{-1}$ mercurychloride was made from $\mathrm{HgCl}_{2}$ (Merck, $99.5 \%$ pure
$\mathrm{Hg}$ ) by diluting with distilled water. A stock solution of $104 \mu \mathrm{g} \mathrm{ml} \mathrm{m}^{-1}$ (pure $\mathrm{Hg}$ ) methylmercurychloride was made from $\mathrm{CH}_{3} \mathrm{HgCl}$ in $5 \mathrm{ml}$ of acetone and diluted to $100 \mathrm{ml}$ with distilled water. Each of the stock solutions were diluted to $1 \mu \mathrm{g} \mathrm{m}^{-1}$. Standards of 0 (= blank); 2.5. $5,10,15$ and $20 \mathrm{ng} \mathrm{Hg}$ were made by adding appropriate volumes of stock solutions to $2.5 \mathrm{ml} \mathrm{KOH} \mathrm{(10} \mathrm{M),} 39$ $\mathrm{ml} \mathrm{NaCl}(2 \%)$ and $1 \mathrm{ml} \mathrm{K}_{2} \mathrm{Cr}_{2} \mathrm{O}_{7}(1 \%)$. The standard solutions were treated as the samples in the analysis procedure.

Calculation of mercury content: Two standard curves were constructed (for inorganic and organic $\mathrm{Hg}$ ) relating peak height (in $\mathrm{mm}$ ) to $\mathrm{ng} \mathrm{Hg}$ in the standards. The curves were then used to derive the mercury content of the samples. The detection limit is twice the blank peak (20 to $30 \mathrm{ppb}$ ).

Test of method: The stability of the mercury standard solutions was studied by analysis of inorganic and organic mercury in: (1) new standards, (2) standards kept at $22^{\circ} \mathrm{C}$ for $24 \mathrm{~h}$, (3) standards kept at $5{ }^{\circ} \mathrm{C}$ for $24 \mathrm{~h}$, and (4) standards incubated at $95^{\circ} \mathrm{C}$ for $30 \mathrm{~min}$ in $\mathrm{KOH}$ (Table 2). It was seen that the organic mercury concentration remained constant while the inorganic fraction disappeared, probably because inorganic mercury was converted to $\mathrm{Hg}^{0}$ which evaporated (Oda \& Ingle 1981). The decomposition time is thus a compromise between complete destruction of the biological material and evaporation of inorganic mercury. A standard decomposition time of 60 min was chosen

The possible influence of biological material in the standards was studied by comparing standards with and without uncontaminated flounder muscle tissue (Table 3). It is seen that the influence of muscle tissue on the standards was negligible. Standards without tissue were therefore used.

The reliability of the CVAAS-method was evaluated both when we made an internal intercalibration with the Danish Isotope Centre, and when we participated in ICES First Round Intercalibration on the Analyses of Methyl Mercury in Biological Tissues (Table 1). The

Table 2. Stability of standard solutions of inorganic mercury (Inorg.) and organic mercury (Org.). Mercury concentrations are expressed as pen-recorder peak height in $\mathrm{mm}$

\begin{tabular}{|c|c|c|c|c|c|c|c|c|}
\hline \multirow[t]{2}{*}{$\begin{array}{l}\text { Samples } \\
\text { (ng Hg) }\end{array}$} & \multicolumn{2}{|c|}{$\begin{array}{l}\text { Fresh prepared } \\
\text { standards }\end{array}$} & \multicolumn{2}{|c|}{$\begin{array}{l}\text { Standards incu- } \\
\text { bated } 24 \text { h at } 22^{\circ} \mathrm{C}\end{array}$} & \multicolumn{2}{|c|}{$\begin{array}{l}\text { Standards incu- } \\
\text { bated } 24 \mathrm{~h} \text { at } 5^{\circ} \mathrm{C}\end{array}$} & \multicolumn{2}{|c|}{$\begin{array}{l}\text { Standards incubated } 30 \mathrm{~min} \\
\text { in } \mathrm{KOH}(10 \mathrm{M}) \text { at } 95^{\circ} \mathrm{C}\end{array}$} \\
\hline & Inorg. & Org. & Inorg & Org. & Inorg. & Org. & Inorg. & Org. \\
\hline 0 & 11 & 4 & 13 & 5 & 6 & 7 & 2 & 6 \\
\hline 5 & 32 & 27 & 2 & 21 & 10 & 29 & 17 & 28 \\
\hline 10 & 59 & 59 & 17 & 41 & 24 & 53 & 31 & 51 \\
\hline 15 & 75 & 71 & 16 & 75 & 18 & 75 & 54 & 68 \\
\hline 20 & 90 & 100 & 36 & 98 & 46 & 96 & 57 & 101 \\
\hline 25 & 123 & 122 & 34 & 125 & 47 & 132 & 92 & 128 \\
\hline
\end{tabular}


Table 3. Recovery of mercury in standard solutions with inorganic mercury (Inorg.) and organic mercury (Org.) without or added uncontaminated flounder muscle tissue $(0.25 \mathrm{~g}$ wet $\mathrm{wt})$. The concentrations are expressed as pen-recorder peak height in mm

\begin{tabular}{|c|c|c|c|c|c|c|}
\hline \multirow{2}{*}{$\begin{array}{l}\text { Samples } \\
\text { (ng Hg) }\end{array}$} & \multicolumn{2}{|c|}{ Without tissue } & \multicolumn{2}{|c|}{ With tissue } & \multicolumn{2}{|c|}{ Recovery } \\
\hline & Inorg. & Org. & Inorg. & Org. & Inorg. & Org. \\
\hline 0 & 4 & 3 & 2 & 6 & - & - \\
\hline 2.5 & 16 & 15 & 18 & 19 & 113 & 108 \\
\hline 5 & 29 & 28 & 30 & 30 & 112 & 96 \\
\hline 10 & 60 & 59 & 71 & 59 & 123 & 95 \\
\hline 15 & 91 & 84 & 74 & 67 & 83 & 75 \\
\hline \multirow[t]{2}{*}{20} & 117 & 109 & 104 & 88 & 90 & 77 \\
\hline & & & & Mean $\pm S D$ & $108 \pm 21$ & $90 \pm 14$ \\
\hline
\end{tabular}

ICES intercomparison exercise report (Thibaud \& Cossa 1988) concluded that it was 'not possible to point out one type of method offering better results than another'. from the curves in Fig. 1 qualified estimate of the mercury content per $10^{6}$ cells may be found as $150 \times(0.965 / 100)=1.5 \mathrm{ng} \mathrm{Hg}$ at an algal concentration of 7 to $8 \times 10^{3}$ cells $\mathrm{ml}^{-1}$.

\section{Laboratory mussel experiment}

\section{Algal and mussel experiments}

\section{Algal experiment}

Fig. 1 shows the accumulation of inorganic mercury in Phaeodactylum tricornutum as a function of time when exposed to $100 \mathrm{ppb} \mathrm{Hg}$. It can be seen that the accumulation is rapid within the first $25 \mathrm{~min}$, but then levels off to reach a plateau within 100 to $300 \mathrm{~min}$. The

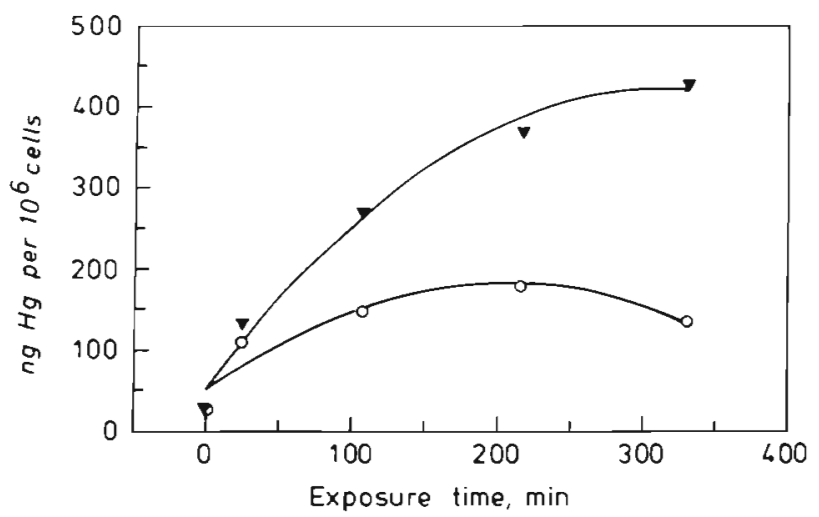

Fig. 1. Phaeodactylum tricornutum. Accumulation of inorganic mercury in 2 experiments with different algal concentrations $\left(\nabla \cdot 6 \times 10^{4} ; 0: 2 \times 10^{5}\right.$ cells $\mathrm{ml}^{-1}$ ) exposed to $100 \mathrm{ppb} \mathrm{Hg}$. Second order regression lines are shown

accumulation rate and the plateau is influenced by the algal concentration: a lower algal concentration results in a more rapid uptake and a higher plateau. A mean algal residence time of about 10 min can be calculated for the 'laboratory mussel experiment' in which $965 \mathrm{ng}$ $1^{-1}$ inorganic mercury was added to the water. Judging
The accumulation of inorganic and organic mercury in 2 size groups of Mytilus edulis is shown in Fig. 2. The accurnulation of both organic and inorganic mercury was linear during the exposure period (mean algal concentration was $7.8 \pm 2.3 \times 10^{3}$ cells $\mathrm{ml}^{-1}$ ). The accumulation rate appears size dependent; the smaller mussels (Group I) had a faster uptake rate of inorganic mercury than the larger mussels (Group II). The filtration rate is estimated to be 28 and $34 \mathrm{ml} \mathrm{min}^{-1}$ ind. ${ }^{-1}$ in Groups I and II, respectively. The daily ingestion is estimated at $315 \times 10^{6}$ cells ind ${ }^{-1}$ in Group I and $382 \times$ $10^{6}$ cells ind. $^{-1}$ in Group II. If the inorganic mercury content per $10^{6}$ cells is ca $1.5 \mathrm{ng} \mathrm{Hg}$ (see 'algal experiment') the daily inorganic mercury ingestion via food is 473 and $573 \mathrm{ng}$ for Groups I and II respectively. The ingestion rates may be compared to the actual uptake of 41.2 and $28.0 \mathrm{ng}$ inorganic $\mathrm{Hg} \mathrm{g}^{-1} \mathrm{~d}^{-1}$ for the 2 groups (Fig. 2), or 21.8 and $19.9 \mathrm{ng} \mathrm{Hg} \mathrm{d}^{-1}$ ind $^{-1}$ for Groups I and II, respectively. The total inorganic mercury intake via food as related to the total actual accumulated amount of inorganic mercury (i.e. the assimilation efficiency) is $(0.0218 / 0.473) \times 100=5 \%$ (Group I) and $(0.0199 / 0.573) \times 100=4 \%$ (Group II) The total amount of inorganic mercury ingested via food may thus easily account for the entire mercury uptake (i.e. uptake directly from the surrounding water may be insignificant).

Though the concentration of organic mercury (methylmercury) used in the experiment is nearly 30 times lower than the exposure concentration of inorganic mercury, the uptake rate of organic mercury is 50 to $75 \%$ of the inorganic uptake rate. This shows that 

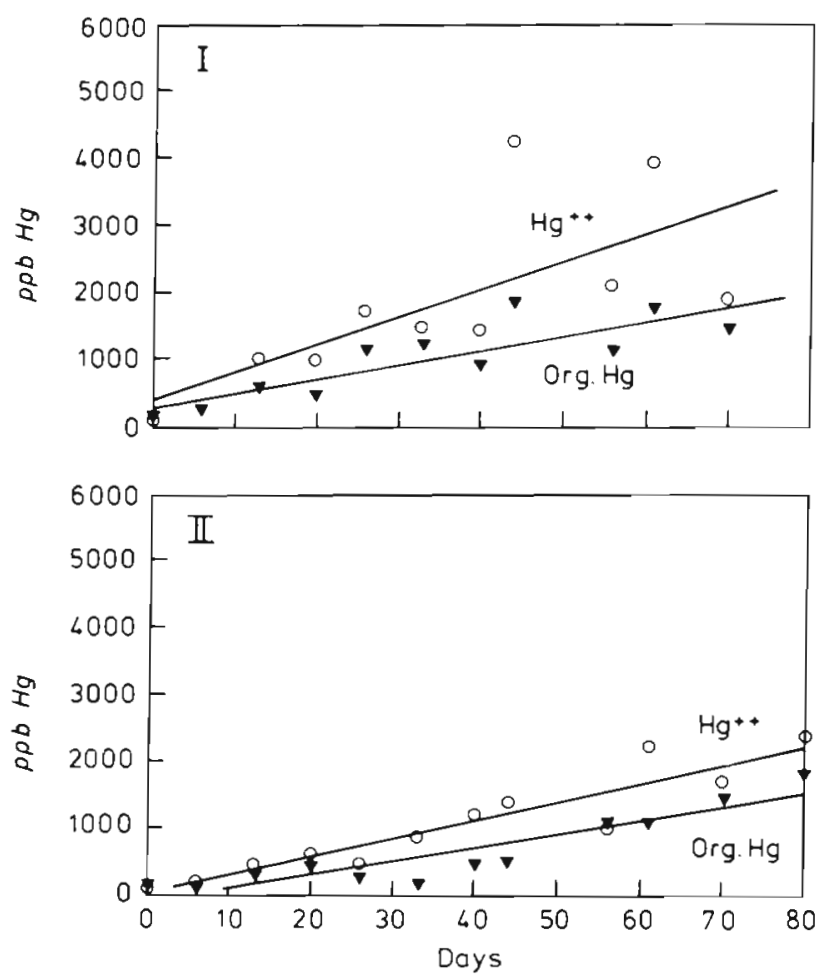

Fig. 2. Mytilus edulis. Accumulation of mercury in 'small' mussels (Group I: $27 \pm 2 \mathrm{~mm}$ shell length; $0.53 \pm 0.06 \mathrm{~g}$ wet wt of soft parts) and 'large' mussels (Group Ir: $31 \pm 2 \mathrm{~mm}$ shell length; $0.71 \pm 0.13 \mathrm{~g}$ wet $\mathrm{wt}$ ) exposed to $35 \mathrm{ng} \mathrm{l^{-1 }}$ organic mercury and $965 \mathrm{ng}^{-1}$ inorganic mercury in laboratory experiments' Mean values of measurements on 2 to 6 individuals are shown together with the regression lines for the linear relation $\mathrm{X}\left(\mathrm{ng} \mathrm{Hg} \mathrm{g}^{-1}\right.$ wet $\left.\mathrm{wt}=\mathrm{ppb}\right)=\mathrm{a}+\mathrm{bX}$ (days). The regression constants $a$ and $b$, and the correlation coefficient $\mathrm{r}$ are Group I: inorganic mercury $(\mathrm{a}=385.5, \mathrm{~b}=41.2$, $r=0.722)$ and organic mercury $(a=254.7, b=21.8, r=$ 0.848); Group II: inorganic mercury $(\mathrm{a}=15.1, \mathrm{~b}=28.0, \mathrm{r}=$ $0.934)$ and organic mercury $(a=-134.6, b=21.1, r=0.934$ )

organic mercury may be taken up at least 15 times more readily than inorganic mercury.

\section{Field mussel experiment}

Mytilus edulis transferred from clean water to the polluted Nissum Broad accumulated both organic and inorganic mercury. Since no differences in uptake rate could be detected between the 3 localities, all data have been pooled (Fig. 3). From the slopes of the regression lines it is seen that the uptake rate of inorganic mercury exceeds that of organic mercury by a factor of $1.85 / 0.42$ $=4.4$. The inorganic uptake rate of $1.85 \mathrm{ng} \mathrm{Hg} \mathrm{g}^{-1}$ wet wt $d^{-1}$ is about 15 to 20 times lower than measured in the 'Laboratory experiment' with $965 \mathrm{ng} \mathrm{l}^{-1}$ inorganic mercury added to the seawater. Thus, the mean concentration of inorganic mercury in the Nissum Broad is

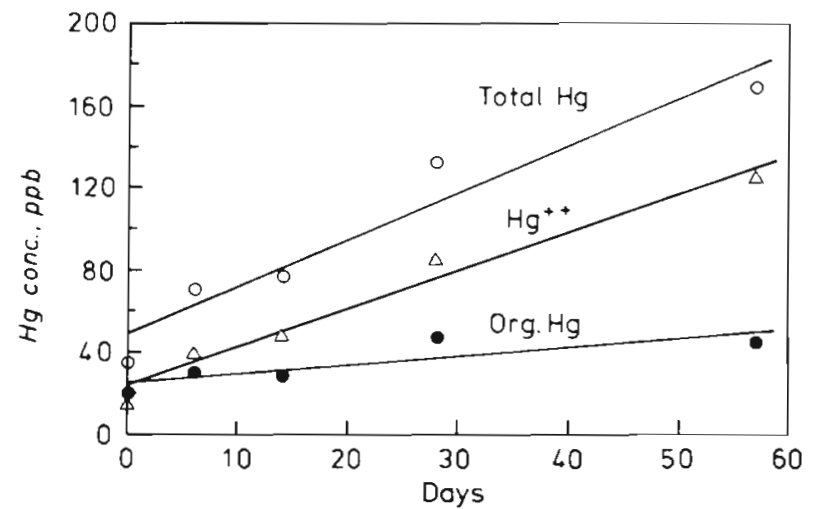

Fig. 3. Mytilus edulis. Accumulation of organic mercury (org. $\mathrm{Hg}$ ), inorganic mercury $\left(\mathrm{Hg}^{++}\right)$and total mercury (org. $\mathrm{Hg}+$ $\mathrm{Hg}^{++}$) in mussels (48.1 $\pm 5.4 \mathrm{~mm}$ shell length; $2.22 \pm 0.71 \mathrm{~g}$ wet wt) transplanted in net bags to the chronically polluted southwestern part of the Nissum Broad, Denmark. Mean values of 5 to 15 measurements on single individuals are shown together with the regression lines for the linear relation $Y$ (ng $\mathrm{Hg} \mathrm{g}^{-1}$ wet $\left.\mathrm{wt}=\mathrm{ppb}\right)=\mathrm{a}+\mathrm{bX}$ (days). The regression constants $a$ and $b$, and the correlation coefficient $r$ are: total $\mathrm{Hg}(\mathrm{a}=48.70, \mathrm{~b}=2.27, \mathrm{r}=0.967) ;$ org. $\mathrm{Hg}(\mathrm{a}=25.39, \mathrm{~b}=$ $0.42, r=0.827) ; \operatorname{Hg}^{++}(a=23.31, b=1.85, r=0.986)$

probably around $50 \mathrm{ng}^{-1}$. The accumulation rate of organic mercury was 21.8 and $21.2 \mathrm{ng} \mathrm{Hg} \mathrm{g}^{-1}$ wet wt $\mathrm{d}^{-1}$ in the 'laboratory experiment' (Fig. 2). An uptake rate of $0.42 \mathrm{ng}$ org. $\mathrm{Hg} \mathrm{g}^{-1}$ wet wt $\mathrm{d}^{-1}$ in mussels transplanted to the Nissum Broad seems to indicate that the organic mercury concentration in the Nissum Broad may be ca 50 times lower than in the laboratory experiment, i.e. about $0.7 \mathrm{ng} \mathrm{Hg} \mathrm{I}{ }^{-1}$.

\section{Fish experiments}

Flounders Platichthys flesus force-fed with mercurycontaminated food (Table 1) readily accumulated organic mercury (methylmercury) in blood cells, liver, kidney and muscle-tissue, while inorganic mercury was only accumulated in measurable amounts in liver and kidney (Fig. 4). No mercury could be detected in the blood plasma. The concentration of organic mercury ( $Y$, ppb wet wt) in the gall bladder (whole organ with fluid) varied considerably, but increased significantly with time ( $\mathrm{X}$, days) as described by the regression equation: $\mathrm{Y}$ $=9.6+1.9 X(r=0.74, n=27, p<0.01)$. No inorganic mercury could be detected in the gall bladder. At the end of the accumulation experiment (Day 46) the organic mercury concentration in the gall bladder is estimated at $97 \mathrm{ppb}$ from the regression equation. This value may be compared to $189 \mathrm{ppb}$ estimated for organic mercury in the blood cells and $363 \mathrm{ppb}$ in the liver where the most pronounced organic mercury accumulation is observed

During the elimination experiment, prior to which flounders were force-fed for 6 wk with mercury-con- 
Fig. 4. Platichthys flesus. Uptake of organic mercury ( 4 ) and inorganic mercury ( $\rightarrow$ ) in blood cells, liver, kidney and muscle as a function of time in accumulation experiment' with flounders force-fed mercury contaminated food for $46 \mathrm{~d}$. Mean values $\pm \mathrm{SE}$ of 4 or 5 samples are shown together with the regression lines for the linear relation: $Y$ (ng $\mathrm{Hg} \mathrm{g}^{-1}$ wet $\mathrm{wt}=\mathrm{ppb}$ ) $=\mathrm{a}+\mathrm{bX}$ (days). The regression constants $a$ and $b$, and the correlation coefficient $r$ are blood cells: organic $\mathrm{Hg}(\mathrm{a}=-12.4, \mathrm{~b}=4.38, \mathrm{r}=0.956)$, inorganic $\mathrm{Hg}(\mathrm{a}=-0.22, \mathrm{~b}=0.12$, $\mathrm{r}=0.641)$ : liver: organic $\operatorname{Hg}(\mathrm{a}=6.36, \mathrm{~b}=$ 7.76, $\mathrm{r}=0.962)$, inorganic $\mathrm{Hg}(\mathrm{a}=-7.64, \mathrm{~b}$ $=2.48, \mathrm{r}=0.968)$; kidney: organic $\mathrm{Hg}(\mathrm{a}=$ $-9.97, b=4.94, r=0.934)$, inorganic $\mathrm{Hg}$ (a $=-1.06, \mathrm{~b}=1.56, \mathrm{r}=0.943)$; muscle: organic $\mathrm{Hg}(\mathrm{a}=24.91, \mathrm{~b}=2.42, \mathrm{r}=0.765)$, inorganic $\mathrm{Hg}(\mathrm{a}=3.57, \mathrm{~b}=0.02, \mathrm{r}=0.043)$

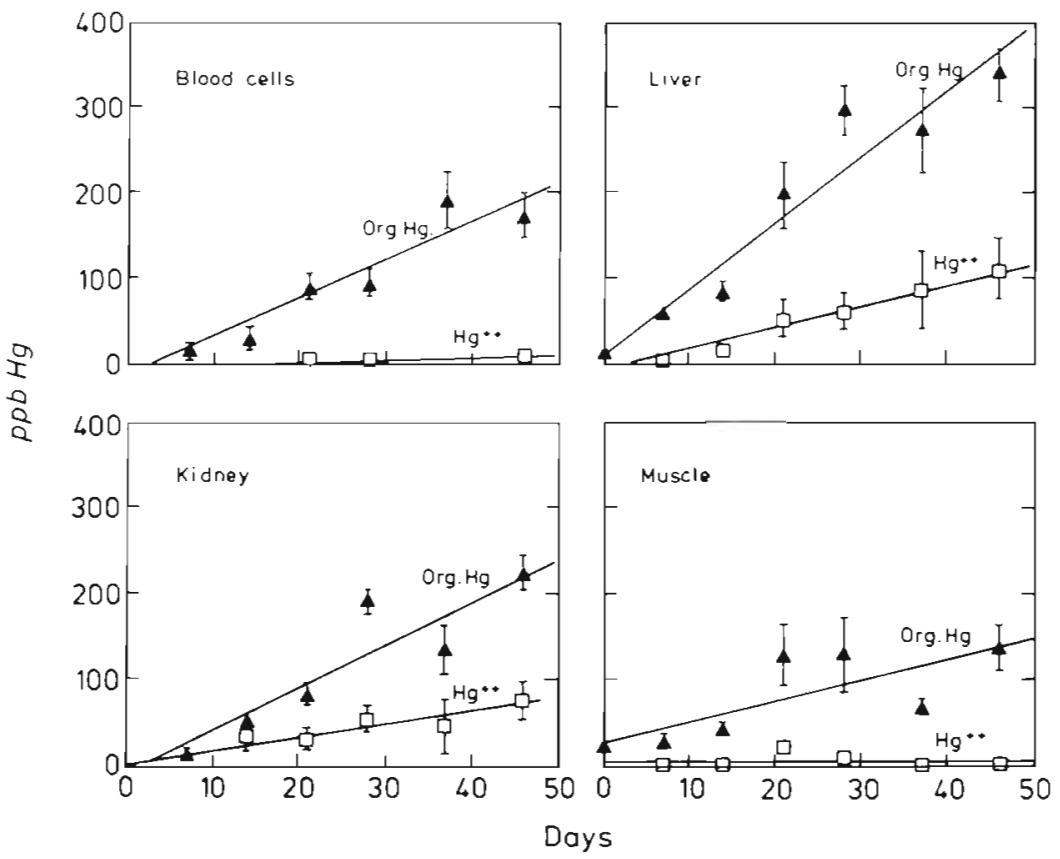

between fed and starved flounders could be detected in the elimination experiment.

The force-feeding of flounders with mercury-contaminated food (1150 ng organic $\mathrm{Hg} \mathrm{g}^{-1}$ wet wt and $1523 \mathrm{ng}$ inorganic $\mathrm{Hg} \mathrm{g}^{-1}$ wet $\mathrm{wt}_{\text {; }}$ see Table 1) over $46 \mathrm{~d}(20$ feedings) resulted in a cumulative mercury food-dose (CD) of $46 \mu \mathrm{g}$ organic $\mathrm{Hg}$ and $60.9 \mu \mathrm{g}$ inorganic $\mathrm{Hg}$. These values may be compared to the total amount of the 2 mercury species actually accumulated in the fish body (TB). The accumulation efficiency, defined as TB/CD, mercury in the liver. No mercury level differences

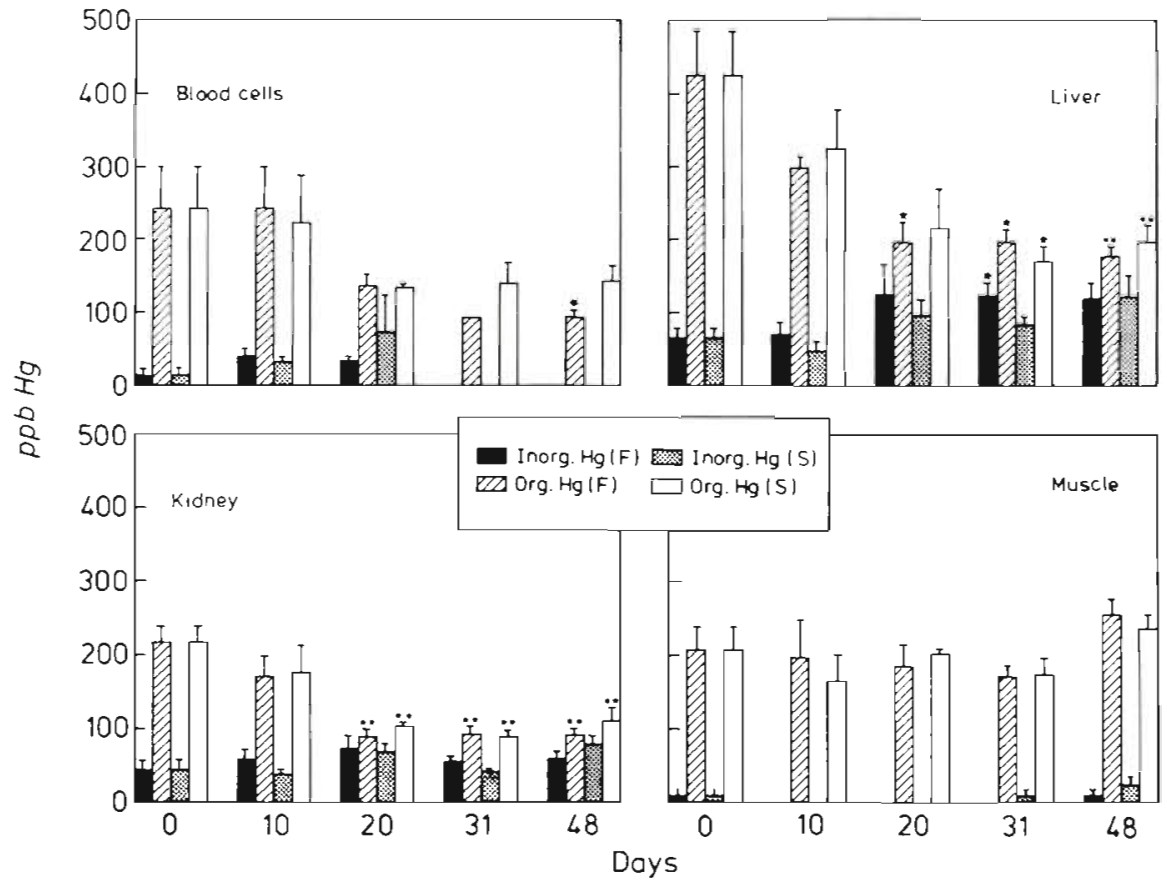

Fig. 5. Platichthys flesus. Concentrations of organic and inorganic mercury (ng $\mathrm{Hg} \mathrm{g}^{-1}$ wet wt $=\mathrm{ppb}$ ) in blood cells, liver, kidney and muscletissue in 'elimination experiment' with flounders loaded with mercury prior to the elimination period of $48 \mathrm{~d}$ during which the fish were either starved (S) or force-fed (F) uncontaminated food. Columns show mean values of 3 to 7 samples and SE is indicated for each group. Asterisks indicate significance level for actual elimination day related to Day 0 (i.e. $3 \mathrm{~d}$ after last force-feeding with mercury contaminated food); $p<0.05$, $\cdots p<0.01$ 
may then be found and used to give a rough estimate of the relative absorption efficiency in the digestive system of the 2 mercury species. The mean total body weight in the group of 5 flounders sampled on Day 46 was $208 \pm 42$ $\mathrm{g}$ (range 156 to $266 \mathrm{~g}$ ). The mean liver and kidney weights were 3.8 and $1.1 \mathrm{~g}$, respectively. If it is assumed that $55.5 \%$ of the total body mass is made up of muscle-tissue and if $1.5 \%$ of the body mass is blood cells (Pentreath 1976) then the concentrations of mercury in the remaining tissues are calculated to be $14.8 \mu \mathrm{g}$ organic $\mathrm{Hg}$ and $0 \mu \mathrm{g}$ inorganic $\mathrm{Hg}$ in muscle-tissue, $1.6 \mu \mathrm{g}$ organic $\mathrm{Hg}$ and $0.36 \mu$ inorganic $\mathrm{Hg}$ in liver, $0.25 \mu \mathrm{g}$ organic $\mathrm{Hg}$ and $0.08 \mu \mathrm{g}$ inorganic $\mathrm{Hg}$ in kidney, $0.55 \mu \mathrm{g}$ organic $\mathrm{Hg}$ and $0.03 \mu \mathrm{g}$ inorganic $\mathrm{Hg}$ in blood cells. Thus the total body load is $17.2 \mu \mathrm{g}$ organic $\mathrm{Hg}$ and $0.5 \mu \mathrm{g}$ inorganic $\mathrm{Hg}$, which gives rise to accumulation efficiencies of 34 and $1 \%$, respectively. Because nearly $90 \%$ of the total amount of organic mercury accumulated in the fish is found in the muscle-tissue (from which it is not eliminated; Fig. 5) it may be concluded that the absorption efficiency of organic mercury (i.e. methylmercury in the present case) in the digestive system is at least $34 \%$. This is a minimum figure because mercury is also being taken up in other parts of the fish not accounted for in this study (brain, central nervous system, skeleton, intestine, spleen, gonads etc.). Though relocation of mercury from blood to liver takes place, and though some organic mercury may be biotransformed in the liver and eventually excreted via the gall bladder to the intestine from where it may be taken up again, i.e. enterohepatic recirculation; Rabenstein 1978), only an insignificant amount of the accumulated mercury can have been eliminated during the accumulation experiment (see 'Discussion' and Table 4). This statement justifies the straight lines drawn for the accumulation of organic mercury in mussel-tissue as a function of time - and (to some extent) the straight lines shown for liver, blood and kidney in Fig. 4.

\section{DISCUSSION}

\section{Mercury analyses}

Tests of the stepwise-reduction-CVAA-method (cf. 'Materials and methods', Tables 1,2 and 3) showed that the method provides an reliable and effective technique for studying biomagnification of mercury in food-chains.

\section{Algal and mussel experiments}

In a previous study, mussels Mytilus edulis were also transferred from clean water to the polluted Nissum Broad (Riisgård et al. 1985). It was found that the mussels readily accumulated mercury during the expo- sure period of $3 \mathrm{mo}$. The mean daily weight-specific mercury uptake was 20.2 and $16.9 \mathrm{ng}$ total mercury $\mathrm{g}^{-1}$ wet wt for 2 groups of 0.48 and $0.45 \mathrm{~g}$ mean wet wt mussels, respectively. In the present study the uptake rate was $2.27 \mathrm{ng}$ total mercury $\mathrm{g}^{-1}$ wet wt for a mean 2.22 $g$ wet wt mussel (Fig. 3). The lower uptake rate in this study may be due to both an actual decrease in the mercury pollution level in the Nissum Broad as well as a lower weight-specific accumulation rate in the larger mussels used in this study. A decreasing weight-specific mercury accumulation rate with increasing body weight has been demonstrated by Riisgård et al. (1985) and interpreted to be due to a decrease both in weightspecific filtration rate and surface area to volume ratio in mussels with increasing size. The larger uptake rate (4.4 times) of inorganic mercury as related to organic mercury (Fig. 3) is in accordance with earlier measurements of inorganic and organic mercury in $M$. edulis from the Nissum Broad (Riisgård et al. 1985) where it was found that about $75 \%$ of the total mercury in the locally collected mussels was in the inorganic form. In a recent study Møhlenberg \& Riisgård (1988) found that the partitioning of inorganic and organic mercury in cockles Cardium edule and C. glaucum was age-dependent. In 2-, 3- and 4-yr-old cockles organic mercury constituted ca 30,60 , and $90 \%$ of the total mercury, respectively. This phenomenon, which can probably also be found in Mytilus edulis may be due to a higher depuration rate of inorganic mercury than of organic mercury when the uptake rate exceeds the immobilization capacity of the mussels (Riisgård et al. 1985). As fish such as flounder may primarily feed on juvenile bivalves it is likely that most (probably $>75 \%$ ) of the mercury ingested by such fish (in the Nissum Broad) is in the inorganic form.

The estimated assimilation efficiency of inorganic mercury (about $5 \%$ ) may appear low (Fig. 1). If the cell volume of Phaeodactylum tricornutum is about $90 \mathrm{~km}^{3}$ and $10^{6}$ cells contain $1.5 \mathrm{ng}$ inorganic mercury when exposed to $965 \mathrm{ng} \mathrm{l}^{-1}$ it can be estimated that the volume/ volume concentration factor is $1.8 \times 10^{4}$ This value is in reasonable agreement with the findings of Fisher et al. (1984) who found concentration factors of mercury $\left({ }^{203} \mathrm{Hg}\right)$ between 3.2 and $9.5 \times 10^{4}$ in 4 marine algal species. Thus, it is justified to conclude that about $5 \%$ of the inorganic mercury ingested via food in Mytilus edulis is assimilated. A larger fraction of the ingested mercury may, however, be absorbed in the digestive system, but may then rapidly be excreted again.

\section{Fish experiments}

Methylmercury (i.e. organic mercury in this study) is rapidly incorporated into the blood after passage through the intestinal wall. The largest concentration 
of organic mercury in whole blood is generally found in the red blood cells, and the role of erythrocytes as carrier of methylmercury to various organs is well established (Clarkson 1972, Giblin \& Massaro 1973, Doi \& Tagawa 1983). No mercury could be detected in the blood plasma in the present study, and only low, but slightly increasing, concentrations of inorganic mercury during the exposure period were found in blood cells (Fig. 4). In a previous study no mercury could be detected in the blood plasma from flounders Platichthys flesus from the chronically polluted Nissum Broad, and $83 \%$ of the total mercury measured in blood cells (218 ppb wet wt) was organic (Riisgård \& Famme 1988). Penthreath (1976) studied the accumulation of inorganic mercury and methylmercury in force-fed plaice Pleuronectes platessa and found, in accordance with the present work, that little of the inorganic form was retained while the methylmercury was readily absorbed by the intestine. Boudou \& Ribeyre (1985) made a quantitative analysis of 'trophic exposure' of rainbow trout Salmo gairdneri fed on 'prey' contaminated with $\mathrm{HgCl}_{2}$ and $\mathrm{CH}_{3} \mathrm{HgCl}$. The highest concentrations of mercury occurred in the 'predator' after ingestion of prey contaminated with the organic form. Further, it was revealed that the intestine functions as a barrier to the uptake of inorganic mercury. The concentration ratio of inorganic to organic mercury in the posterior intestine was about 5 after $30 \mathrm{~d}$ of contamination. In experiments with rainbow trout exposed to methylmercury via the food, Phillips \& Buhler (1978) found that the fish accumulated methylmercury linearly over $24 \mathrm{~d}$ and that nearly $70 \%$ of the mercury ingested was assimilated. In the present work the accumulation of organic mercury was linear with exposure time (Fig. 4), with a minimum accumulation efficiency of $34 \%$, which to some extent is a measure of the 'assimilation' or 'absorption efficiency' as frequently used synonymously in the literature. Values up to about $90 \%$ have been reported, though a few workers have found 'assimilation' values below $20 \%$ (cf. Phillips \& Gregory 1979, their Table 2). The 2 feces samples in Table 4 indicate absorption efficien- cies of $63 \%$ for inorganic and $86 \%$ for organic mercury. It is, however, not possible to judge how much of the 2 mercury species have actually been absorbed and how much of the mercury has only been bound to epithelial cells in the intestine. The latter phenomenon may very well be the case for inorganic mercury. How and in which chemical forms the mercury species are absorbed by the gut is not known (Gutknecht 1981, Boudou et al. 1983, Bienvenue et al. 1984), but the digestive wall may be considered to be a permeable biological structure to the relatively liposoluble methylmercury and a much more efficient barrier to inorganic mercury.

In the present work organic mercury was taken up in liver, kidney and muscle-tissue at approximate rates of 8, 5 and $2 \mathrm{ng} \mathrm{Hg} \mathrm{g}^{-1}$ wet wt $\mathrm{d}^{-1}$, respectively (Fig. 4). The organ distribution of mercury and the relatively high accumulation rate (especially of organic mercury in the liver) confirm earlier findings in fish (Burrows \& Krenkel 1973, Pentreath 1976, Boudou \& Ribeyre 1985). Both inorganic and organic mercury are extracted from the blood as it circulates through the liver, and the present work partly explains the previous observation that the concentrations of the 2 mercury forms were about the same in the liver in flounders caught in the mercury-polluted Nissum Broad (Riisgård \& Famme 1988). Prey organisms from the same area (e.g. bivalves) showed inorganic and organic mercury concentrations comparable to those applied in food used in the force-feeding experiments in the present work (Riisgård et al. 1985, Møhlenberg \& Riisgård 1988). About $94 \%$ of the total mercury in the above-mentioned chronically contaminated flounders was found to be organic. This is in agreement with the accumulation pattern of the 2 mercury forms in the muscle tissue in the present work (Fig. 4).

The indication of biotransformation of organic mercury to inorganic mercury in the liver (Fig. 5) is in accordance with similar findings in both fish (Burrows \& Krenkel 1973, Olson et al. 1978) and mammals (Norseth \& Clarkson 1971, Rabenstein 1978). Bile is the main route for the elimination of methylmercury from the liver (Ballatori \& Clarkson 1983), but the

Table 4. Platichthys flesus. Mean inorganic mercury (Inorg. $\mathrm{Hg}$ ) and organic mercury (Org. Hg) $\pm \mathrm{SD}$ in samples of feces from the proximal (P) and distal (D) part of the intestine in flounders taken on different days during the 'accumulation experiment' (Expt A)

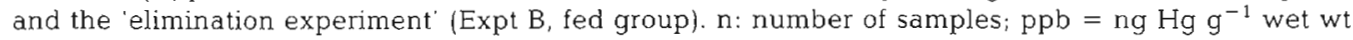

\begin{tabular}{|cccccccc}
\hline Expt & Day & $\mathrm{a}$ & & & & $\mathrm{D}$ \\
& & & Inorg. Hg (pp) & Org. Hg (ppb) & Inorg. Hg (ppb) & Org. Hg (ppb) \\
\hline A & 46 & 2 & & & $565 \pm 277$ & $164 \pm 122$ \\
B & 10 & 3 & $1751 \pm 354$ & $459 \pm 31$ & $936 \pm 85$ & $237 \pm 18$ \\
B & 31 & 3 & $1727 \pm 322$ & $290 \pm 44$ & $741 \pm 167$ & $129 \pm 38$ \\
B & 48 & 6 & $1175 \pm 201$ & $166 \pm 22$ & $704 \pm 116$ & $116 \pm 16$ \\
\hline
\end{tabular}


relatively low concentration of organic mercury in the gall bladder seems to indicate that enterohepatic recirculation (i.e. secretion of organic mercury into the intestinal tract in the liver bile and reabsorption into the blood stream) may not play a similarly significant role for the elimination rate of organic mercury in fish as reported for mammals (Rabenstein 1978). This statement is supported by the lack of difference in mercury distribution and elimination patterns between fed (more bile producing) and starved (less bile producing) flounders in the elimination experiment (Fig. 5). However, the presence of high concentrations of inorganic mercury (about $1100 \mathrm{ppb}$ ) in the proximal part of the intestine $48 \mathrm{~d}$ after the last mercury-contaminated meal (as well as the generally lower concentrations of the 2 mercury species in the distal part of the intestine of flounders fed uncontaminated food; Table 4) show that some mercury may be secreted via the bile, and that some of this mercury may be reabsorbed or bound to the epithelial cells of the intestine during its passage through the gut. The net loss of total mercury from the liver (Fig. 5) supports this statement.

The present work has shown that the ratio of liver. muscle mercury concentration is dynamic. The ratio is $>1$ when uncontaminated fish accumulate mercury, but when mercury is no longer taken up, the liver concentration decreases and the muscle level may after some time exceed the liver level resulting in a liver: muscle ratio $<1$. The efficient accumulation of organic mercury in muscle-tissue and the lack of elimination of mercury from the tissue will result in an increasing mercury concentration with age as confirmed in several studies on fish (Sharpe et al. 1977, Luten et al. 1987. Clark \& Topping 1989). The accumulation of organic mercury during the whole life time makes the liver: muscle ratio (Jernelöv \& Lann 1971, Olson et al. 1978) a somewhat problematic parameter to use in e.g. monitoring programmes, because chronically contaminated fish may show a liver : muscle ratio $<1$ (Riisgård \& Famme 1988) whereas uncontaminated fish that have recently migrated into a mercury polluted area may show a liver muscle ratio $>1$ (as seen during the exposure penod in the present work).

\section{Biomagnification of mercury in the grazing food-chain}

Measurement of the concentration of a pollutant at different levels along a food-chain can show whether the concentration of the pollutant remains constant or not. Increase with trophic levels, 'transfer up the food chain', is called biomagnification (cf. Spacie \& Hamelink 1985). In an earlier study on the total mercury concentration in fish and invertebrates from the
Nissum Broad there was no consistent pattern of total mercury concentration, and it was not possible to demonstrate biomagnification of mercury in the foodchains (Kiørboe et al. 1983). More recent studies on the distribution and the accumulation of inorganic and organic mercury in bivalves Mytilus edulis and Macoma balthica (Riisgård et al. 1985), and shrimp Crangon crangon (Riisgărd \& Famme 1986) strongly emphasized the need to distinguish between organic and inorganic mercury. In the present work it has been possible by means of the stepwise-reduction CVAA-method to study how organic mercury is bioaccumulated in favor of inorganic mercury in a marine grazing food-chain (algae/bivalves/fish) and to describe in more detail the biomagnification process of organic mercury. Field and laboratory results indicated that the main uptake route of mercury in suspension-feeding bivalves may be via the food (i.e. algal cells). The concentration of inorganic mercury and organic mercury in the polluted Nissum Broad has been estimated to be about 50 and $0.7 \mathrm{ng} 1^{-1}$, respectively. Though only about $1 \%$ of the total mercury in the water may be in the organic form, an enhanced uptake rate (at least $15 \times$ ) of organic mercury in suspension feeding mussels leads to differential partitioning of the 2 mercury forms. The percentage of organic mercury increases with the age of the mussels. Since fish such as flounder may primarily feed on juvenile mussels, about $75 \%$ of the total mercury ingested by the fish may be in the inorganic form. Mercury accumulation and elimination studies for flounders force-fed with food contaminated with equal concentrations of organic (methylmercury) and inorganic mercury have shown that the organic mercury is rapidly incorporated in the blood and accumulated in the muscle-tissue. Much less inorganic mercury is accumulated in the blood or mussel-tissue, but is retained in the liver and eventually excreted via the liver bile. The efficient accumulation of organic mercury in muscle-tissue (in which nearly $90 \%$ of the total amount of organic mercury in the fish is found) and the lack of elimination of mercury from the muscle-tissue results in an increasing mercury concentration with both age and trophic level in the marine grazing food-chain. Though many details in the biomagnification process of organic mercury may still be somewhat obscure, the methodology and the experimental approach outlined in the present work may give an answer to these questions in future studies.

Acknowledgements. Thanks are due to Mrs Lone Morgen for technical assistance and Mr Age Hansen, Thyboron, for help with the field studies. Drs Flemming Møhlenberg and Valery Forbes are acknowledged for critically reading the manuscript 


\section{LITERATURE CITED}

Ballatori, N., Clarkson, T W. (1983). Biliary transport of gluthione and methylmercury. Am. J. Physiol. 244: G435-G441

Beljer, K., Jernelöv, A. (1979). Methylation of mercury in aquatic environments. In: Nriagu, J. O. (ed.) The biogeochemistry of mercury in the aquatic environment. Elsevier/North-Holland Biochemical Press, Amsterdam, p. $203-210$

Bienvenue, E., Boudou, A., Desmazès, J. P., Gavach, C. Georgescauld, D., Sandeaux, J., Sandeaux, R., Seta, P. (1984). Transport of mercury compounds across bimolecular lipid membranes: effect of lipid composition, $\mathrm{pH}$ and chloride concentration. Chem. biol. Interactions 48: 91-101

Boudou, A., Georgescauld, D., Desmazès, J. P. (1983). Ecotoxicological role of the membrane barriers in transport and bioaccumulation of mercury compounds. Adv. Envir. Sci. Technol. 13: 117-136

Boudou, A., Ribeyre, F. (1985). Experimental study of trophic contamination of Salmo gairdneri by two mercury compounds $-\mathrm{HgCl}_{2}$ and $\mathrm{CH}_{3} \mathrm{HgCl}$ - analysis at the organism and organ levels. Wat. A.ir Soil Pollut. 26: 137-148

Burrows, W. D., Krenkel, P. A. (1973). Studies on uptake and loss of methylmercury-203 by bluegills (Lepomis macrochirus Raf.). Envir Sci. Technol. 7: 1127-1130

Clark, G., Topping, G. (1989). Mercury concentrations in fish from contaminated areas in Scottish waters. J. mar. biol. Ass. U.K. 69: 437-445

Clarkson, T. W. (1972). Recent advances in the toxicology of mercury with emphasis on the alkylmercurials. CRC critical Rev. Toxicol. 1: 203-230

Clarkson, T W., Hamada, R., Amin-Zaki, L. (1984). Mercury In: Nriagu, J. O. (ed.) Changing metal cycles and human health. Dahlem Konferenzen. Springer-Verlag, Berlin, p. 285-309

Compeau, G., Barthâ, R. (1984). Methylation and demethylation of mercury under controlied redox, $\mathrm{pH}$, and salinity conditions. Appl. environ. Microbiol. 48: 1203-1207

Doi, R., Tagawa, M. (1983). A study on the biochemical and biological behavior of methylmercury. Toxicol. appl. Pharmacol. 69: 407-416

Fisher, N. S., Bohé, M., Teyssié, J.-L. (1984). Accumulation and toxicity of $\mathrm{Cd}, \mathrm{Zn}, \mathrm{Ag}$, and $\mathrm{Hg}$ in four marine phytoplankters. Mar. Ecol. Prog. Ser. 18: 201-213

Gardner, W. S. Kendall, D. R., Odum, R. R., Windom, H. L. Stephens, J. A. (1978). The distribution of methylmercury in a contaminated salt marsh ecosystem. Envir. Pollut. 15: $243-251$

Giblin, F. J., Massaro, E. J. (1973). Pharmacodynamics of methyl mercury in the rainbow trout (Salmo gairdneri) tissue uptake, distribution and excretion. Toxicol appl. Pharmacol. 24: 81-91

Gutknecht, J. (1981). Inorganic mercury $\left(\mathrm{Hg}^{++}\right)$transport through lipid bilayer membranes. J. Membrane Biol. 61: $61-66$

Huckabee, J. W., Elwood, J. W., Hildebrand, S. G. (1979). Accumulation of mercury in freshwater biota. In: Nriagu, J. $O$. (ed.) The biochemistry of mercury in the environment. Elsevier/North-Holland Biomedical Press, Amsterdam, p. $277-307$

Jernelöv, A., Lann, H. (1971). Mercury accumulation in food chains. Oikos 22: 403-406

Kiørboe, T., Møhlenberg, F., Riisgård, H. U. (1983). Mercury levels in fish, invertebrates and sediment in a recently recorded polluted area (Nissum Broad, Western Limfjord, Denmark). Mar Pollut. Bull. 14: 21-24
Knauer, G. A., Martin, J. H. (1972). Mercury in a marine pelagic food chain. Limnol. Oceanogr 17: 868-876

Luten, J. B., Bouquet, W., Riekwel-Booy, G., Rauchbaar, A. B., Scholte, M. W. M. (1987). Mercury in flounder, Platichthys flesus, cod, Gadus morhua, and perch, Perca fluviatilis, in relation to their length and environment. Bull envir. Contam. Toxicol. 38: 318-323

Mikac, N., Picer, M., Stegnar, P., Tusek-Znidaric, M. (1985). Mercury distribution in polluted marine area, ratio of total mercury, methylmercury and selenium in sediment, mussels and fish. Water Res. 19: 1387-1392

Mohlenberg, F., Rilsgård, H. U. (1978). Efficiency of particle retention in 13 species of suspension feeding bivalves. Ophelia 17: 239-246

Møhlenberg. F., Riisgård, H. U. (1979). Filtration rate, using a new indirect technique, in thirteen species of suspensionfeeding bivalves. Mar Biol. 54: 143-148

Mohlenberg, F., Riisgård, H. U. (1988). Partitioning of inorganic and organic mercury in cockles Cardium edule (L.) and $C$ glaucum (Bruguiére) from a chronically polluted area: influence of size and age. Environ. Pollut. 55: 137-148

Norseth, T., Clarkson, T W (1971). Intestinal transport of ${ }^{203} \mathrm{Hg}$-labeled methyl mercury chloride. Arch. environ. Health 22: 568-577

Oda, C. E., Ingle, J. D. Jr (1981). Speciation of mercury by cold vapor atomic absorption spectrometry with selective reduction. Analyt. Chem. 53: 2305-2309

Olson, K. R., Squibb, K. S., Cousins, R. J. (1978). Tissue uptake, subcellular distribution, and metabolism of $\mathrm{CH}_{3} \mathrm{HgCl}$ and $\mathrm{CH}_{3}{ }^{203} \mathrm{HgCl}$ by rainbow trout Salmo gairdneri. J. Fish. Res. Bd Can. 35: 381-39̄0

Pentreath, R. J. (1976). The accumulation of mercury from food by the plaice, Pleuronectes platessa L. J. exp. mar. Biol. Ecol. 25: 51-65

Phillips, G. R., Buhler, D. R. (1978). The relative contributions of methylmercury from food or water to rainbow trout (Salmo gairdneri) in a controlled laboratory environment. Trans. Am. Fish. Soc. 107: 853-861

Phillips, G. R., Gregory, R. W. (1979). Assimilation efficiency of dietary methylmercury by northern pike (Esox lucius). J. Fish. Res. Bd Can. 36: 1516-1519

Rabenstein, D. L. (1978). The chemistry of methylmercury toxicology. J. chem. Education 55: 292-296

Riisgărd, H. U. (1984). Mercury pollution in the waters around Harboere Tange and Limfjord, Denmark. Mar. Pollut. Bull. 15: $129-133$

Riisgård, H. U., Famme, P. (1986). Accumulation of inorganic and organic mercury in shrimp, Crangon crangon. Mar. Pollut. Bull. 17: 255-257

Ruisgård, H. U., Famme, P. (1988). Distribution and mobility of organic and inorganic mercury in flounder, Platichthys flesus, from a chronically polluted area. Toxicol. environ. Chem. 16: 219-228

Riisgård, H. U., Kiørboe, T., Møhlenberg, F., Drabk, I., Pheiffer Madsen, P. (1985). Accumulation, elimination and chemical speciation of mercury in the bivalves Mytilus edulis and Macoma balthica. Mar Biol. 86: 55-62

Sharpe, M. S., deFreitas, A. S. W., McKinnon, A. E. (1977). The effect of body size on methylmercury clearance by goldfish (Crassius auratus). Environ. Biol. Fish. 2: 177-183

Spacie, A., Hamelink, J. L. (1985). Bioaccumulation. In: Rand, G. M., Perocelli, S. R. (eds.) Fundamentals of aquatic toxicology. Hemisphere Publishing Corporation, Washington, p. 495-525

Thibaud, Y., Cossa, D. (1988). ICES first round intercalibration for methyl mercury in biological tissue. Int. Counc. Explor. Sea (ICES 1/CH3HG/BT, May 1988, Final Report) 
Topping, G., Davies, I. M. (1981). Methylmercury production in the marine water column. Nature, Lond. 290: 243-244

Vonk, J. W., Sijpesteijn, A. K. (1973). Studies on the methylation of mercuric chloride by pure cultures of bacteria and fungi. Antonie van Leeuwenhoek 39: 505-513

This article was submitted to the editor
Windom, H. L., Kendall, D. R. (1979). Accumulation and biotransformation of mercury in coastal and marine biota. In: Nriagu, J. O. (ed.) The biochemistry of mercury in the environment. Elsevier/North-Holland Biomedical Press, Amsterdam, p. 303-323

Manuscript first received: October 16, 1989 Revised version accepted: February 6, 1990 